\title{
PELAYANAN HUKUM TERHADAP PENGADAAN \\ BARANG DAN JASA
}

\author{
Oleh \\ Yusri \\ Balai Besar Pelaksanaan Jalan Nasional XI \\ Direktorat Jenderal Bina Marga Kementerian Pekerjaan Umum dan Perumahan Rakyat
}

\begin{abstract}
ABSTRAK
Peraturan Presiden 4 tahun 2015 dinilai oleh banyak pihak sebagai aturan yang akan mendorong pengadaan barang dan jasa akan berjalan secara efektif dan efisen, yaitu perubahan mengenai pengertian pejabat pengadaan. Selama ini pejabat pengadaan sudah terbiasa dengan metode pengadaan langsung. Jika ditambahkan dengan penunjukan langsung untuk batasan nilai yang sama dengan pengadaan langsung, hal itu tidak akan menjadi persoalan yang serius. Karena selama ini pejabat pengadaan tidak ada masalah dengan pemilihan pengelola yang sudah dilakukan sebelumnya. Namun akan menjadi persoalan ketika pejabat pengadaan juga diberi kewenangan untuk pengadaan dengan cara e-purchasing tanpa batasan nilai. Oleh karena itu perlu dikaji tentang etika dan pelayanan hukum terhadap pengelola pengadaan barang dan jasa untuk melaksanakan e-purchasing tanpa batasan nilai. Tujuan yang dicapai pada makalah ini adalah (1) Mengetahui etika pengadaan barang dan jasa pengelola barang dan jasa, (2) Mengetahui pelayanan hukum terhadap pengelola pengadaan barang dan jasa untuk melaksanakan e-purchasing tanpa batasan nilai. Hasil yang didapat adalah (1) Etika pengadaan barang/jasa (2) Pelayanan Hukum Terhadap Pengelola Pengadaan Barang dan Jasa.
\end{abstract}

Kata Kunci: Pelayanan Hukum, Pengadaan Barang dan Jasa.

\section{PENDAHULUAN}

Dengan adanya wacana keterbukaan yang bergulir di Indonesia, menuntut harapan agar pengadaan barang/jasa pemerintah yang dibiayai Anggaran Pendapatan dan Belanja Negara/Anggaran Pendapatan dan Belanja Daerah (APBN/APBD) dapat dilaksanakan secara lebih efektif dan efisien, mengutamakan penerapan prinsip-prinsip persaingan usaha yang sehat, transparan, terbuka, dan berlaku adil bagi semua pihak. Selain lingkup dan cakupan pengadaan barang/jasa pemerintah yang luas, bersifat lintas institusi dan lintas sektor, juga berdampak langsung bagi pengembangan usaha kecil, peningkatan produksi dalam negeri, dan pengembangan iklim dan dunia usaha pada umumnya.

Tujuan utama pengadaan barang/jasa pada instansi pemerintah adalah bukan untuk menghasilkan barang/jasa yang bertujuan profit oriented, tetapi lebih bersifat memberikan pelayanan kepada masyarakat. Pemerintah memerlukan barang/jasa dalam rangka meningkatkan pelayanan publik atas dasar pemikiran yang logis dan sistematis, mengikuti prinsip dan etika serta berdasarkan metode dan proses pengadaan yang berlaku.

Dalam Anggaran Pendapatan dan Belanja Negara (APBN), struktur anggaran belanja mempunyai komponen belanja pegawai, belanja barang, belanja modal, pembayaran bunga cicilan, subsidi, belanja hibah, bantuan sosial, dan belanja lain-lain.

Peraturan Presiden 4 tahun 2015 dinilai banyak pihak sebagai aturan yang akan mendorong pengadaan barang dan jasa akan berjalan secara efektif dan efisen, yaitu perubahan mengenai pengertian pejabat pengadaan. Pasal 1 ayat 9 mengatakan bahwa yang disebut pejabat pengadaan adalah personil yang ditunjuk untuk melaksanakan Pengadaan Langsung, Penunjukan Langsung, dan E-Purchasing.

\section{LANDASAN TEORI \\ Pengadaan Barang Dan Jasa}

Menurut Peraturan Presiden Pasal 1 Nomor 70 Tahun 2012, yang dimaksud dengan :

1. Pengadaan Barang/Jasa adalah kegiatan untuk memperoleh Barang/Jasa oleh Kementerian/ Lembaga/ Satuan Kerja 
Perangkat Daerah/Institusi lainnya yang prosesnya dimulai dari perencanaan kebutuhan sampai diselesaikannya seluruh kegiatan untuk memperoleh barang/jasa.

2. Penunjukan Langsung adalah metode pemilihan Pengelola Barang/Jasa dengan cara menunjuk langsung 1 (satu) Pengelola Barang/Jasa.

3. Pengadaan Langsung adalah Pengadaan Barang/Jasa langsung kepada Pengelola Barang/Jasa, tanpa melalui Pelelangan/ Seleksi/Penunjukan Langsung.

\section{Berlakunya Peraturan Presiden Nomor 4 Tahun 2015}

Peraturan Presiden Nomor 4 Tahun 2015 menimbang berbagai hal yaitu dalam rangka percepatan pelaksanaan belanja Negara guna percepatan pelaksanaan pembangunan, perlu inovasi terhadap pelaksanaan Pengadaan Barang/Jasa Pemerintah yang dilakukan dengan pemanfaatan teknologi informasi, perlu melakukan penyempurnaan terhadap peraturan mengenai Pengadaan Barang/Jasa Pemerintah, perlu menetapkan Peraturan Presiden tentang Perubahan Keempat atas Peraturan Presiden Nomor 54 Tahun 2010 tentang Pengadaan Barang/Jasa Pemerintah. Jenis Pengadaaan Barang/Jasa dalam Peraturan Presiden ini adalah:

1. Barang adalah setiap benda baik berwujud maupun tidak berwujud, bergerak maupun tidak bergerak, yang dapat diperdagangkan, dipakai, dipergunakan atau dimanfaatkan oleh Pengguna Barang.

2. Pekerjaan Konstruksi adalah seluruh pekerjaan yang berhubungan dengan pelaksanaan konstruksi bangunan atau pembuatan wujud fisik lainnya.

3. Jasa Konsultansi adalah jasa layanan profesional yang membutuhkan keahlian tertentu diberbagai bidang keilmuan yang mengutamakan adanya olah pikir (brainware).

4. Jasa Lainnya adalah jasa yang membutuhkan kemampuan tertentu yang mengutamakan keterampilan (skillware) dalam suatu sistem tata kelola yang telah dikenal luas di dunia usaha untuk menyelesaikan suatu pekerjaan atau segala pekerjaan dan/atau pengelolaan jasa selain Jasa Konsultansi, pelaksanaan Pekerjaan Konstruksi dan pengadaan Barang.

\section{Prinsip-prinsip Pengadaan Barang Dan Jasa}

Menurut Peraturan Presiden Nomor 4 Tahun 2015, prinsip-prinsip yang terkandung dalam proses pengadaan barang dan jasa yaitu:

a. Memenuhi ketentuan peraturan perundangundangan untuk menjalankan kegiatan/usaha;

b. Memiliki keahlian, pengalaman, kemampuan teknis dan manajerial untuk menyediakan Barang/Jasa;

c. Memperoleh paling kurang 1 (satu) pekerjaan sebagai Pengelola Barang/Jasa dalam kurun waktu 4 (empat) tahun terakhir, baik di lingkungan pemerintah maupun swasta, termasuk pengalaman subkontrak

d. Memiliki sumber daya manusia, modal, peralatan dan fasilitas lain yang diperlukan dalam Pengadaan Barang/Jasa;

e. Dalam hal Pengelola Barang/Jasa akan melakukan kemitraan, Pengelola Barang/Jasa harus mempunyai perjanjian kerja sama operasi/kemitraan yang memuat persentase kemitraan dan perusahaan yang mewakili kemitraan tersebut;

f. Memiliki kemampuan pada bidang pekerjaan yang sesuai untuk Usaha Mikro, Usaha Kecil, dan koperasi kecil serta kemampuan pada subbidang pekerjaan yang sesuai untuk usaha nonkecil;

g. Memiliki Kemampuan Dasar (KD) untuk usaha non-kecil, kecuali untuk Pengadaan Barang dan Jasa Konsultansi;

h. Khusus untuk Pelelangan dan Pemilihan Langsung Pengadaan Pekerjaan 
Konstruksi memiliki dukungan keuangan dari bank

i. Tidak dalam pengawasan pengadilan, tidak pailit, kegiatan usahanya tidak sedang dihentikan dan/atau direksi yang bertindak untuk dan atas nama perusahaan tidak sedang dalam menjalani sanksi pidana, yang dibuktikan dengan surat pernyataan yang ditandatangani Pengelola Barang/Jasa

Pengelola Barang/Jasa adalah badan usaha atau orang perseorangan yang menyediakan Barang/Pekerjaan Konstruksi/ Jasa Konsultansi/ Jasa Lainnya.

\section{Etika Dan Sanksi Pengelola Pengadaan Barang/Jasa}

Menurut Peraturan Presiden Nomor 4 Tahun 2015, prinsip-prinsip yang terkandung dalam proses pengadaan barang dan jasa yaitu:

a. Memenuhi ketentuan peraturan perundangundangan untuk menjalankan kegiatan/usaha;

b. Memiliki keahlian, pengalaman, kemampuan teknis dan manajerial untuk menyediakan Barang/Jasa;

c. Memperoleh paling kurang 1 (satu) pekerjaan sebagai Pengelola Barang/Jasa dalam kurun waktu 4 (empat) tahun terakhir, baik di lingkungan pemerintah maupun swasta, termasuk pengalaman subkontrak

d. Memiliki sumber daya manusia, modal, peralatan dan fasilitas lain yang diperlukan dalam Pengadaan Barang/Jasa;

e. Dalam hal Pengelola Barang/Jasa akan melakukan kemitraan, Pengelola Barang/Jasa harus mempunyai perjanjian kerja sama operasi/kemitraan yang memuat persentase kemitraan dan perusahaan yang mewakili kemitraan tersebut;

f. Memiliki kemampuan pada bidang pekerjaan yang sesuai untuk Usaha Mikro, Usaha Kecil, dan koperasi kecil serta kemampuan pada subbidang pekerjaan yang sesuai untuk usaha non-kecil; g. Memiliki Kemampuan Dasar (KD) untuk usaha non-kecil, kecuali untuk Pengadaan Barang dan Jasa Konsultansi;

h. Khusus untuk Pelelangan dan Pemilihan Langsung Pengadaan Pekerjaan Konstruksi memiliki dukungan keuangan dari bank

i. Tidak dalam pengawasan pengadilan, tidak pailit, kegiatan usahanya tidak sedang dihentikan dan/atau direksi yang bertindak untuk dan atas nama perusahaan tidak sedang dalam menjalani sanksi pidana, yang dibuktikan dengan surat pernyataan yang ditandatangani Pengelola Barang/Jasa

\section{Pengendalian dan Penawaran Pengadaan Barang/Jasa}

Perbuatan/Tindakan Penyedia dikenakan sanksi administratif dan/atau daftar hitam dan/atau gugatan secara perdata dan/atau pelaporan secara pidana adalah:

1. Berusaha mempengaruhi ULP/PP/pihak lain yang berwenang untuk melanggar ketentuan

2. Melakukan persekongkolan dengan penyedia lain untuk mengatur proses pengadaan

3. Membuat dan/atau menyampaikan dokumen yang tidak benar/palsu

4. Mengundurkan diri dari pelaksanaan kontrak dengan alasan yang tidak dapat dipertanggung jawabkan/diterima oleh $\mathrm{ULP} / \mathrm{PP}$

5. Tidak dapat menyelesaikan pekerjaan sesuai dengan kontrak

Perbuatan/Tindakan Penyedia dikenakan sanksi administratif daftar hitam dan finansial, adalah ditemukan adanya ketidaksesuaian dalam penggunaan Barang/Jasa produksi dalam negeri

Perbuatan/Tindakan Penyedia dikenakan sanksi denda keterlambatan sebesar 1 /1000 per hari dari harga kontrak atau bagian kontrak, maksimal sebesar Jaminan Pelaksanaan Menyusun kembali perencanaan dengan biaya sendiri dan/atau tuntutan ganti rugi, adalah terlambat 
menyelesaikan pekerjaan Konsultan Perencana yang tidak cermat dan mengakibatkan kerugian negara

Perbuatan/Tindakan ULP/Penjabat Pengadaan dikenakan sanksi Administratif dituntut ganti rugi dan/atau dilaporkan secara pidana, adalah adanya Pelanggaran dan/atau kecurangan dalam Proses Pengadaan

Perbuatan/Tindakan ULP/Penjabat Pengadaan dikenakan sanksi sesuai peraturan perundang-undangan, adalah kecurangan dalam pengumuman pengadaan

Perbuatan/Tindakan PPK yang dikenakan sanksi membayar bunga terhadap nilai tagihan yang belum dibayar, atau membayar kompensasi sesuai dengan ketentuan dalam kontrak adalah melakukan cedera janji terhadap ketentuan yang termuat dalam kontrak (misalnya: Keterlambatan pembayaran)

\section{Perbedaan Antara Perpres No. 70 Tahun 2012 dengan Perpres No. 4 Tahun 2015}

Menurut Peraturan Presiden Nomor 4 Tahun 2015, Pelayanan Hukum Terhadap Pengelola Pengadaan Barang dan Jasa yaitu:

1. Pasal 115 ayat 3 menyatakan bahwa Pimpinan K/L/D/I wajib memberikan pelayanan hukum kepada PA/KPA/PPK/ULP/Pejabat

Pengadaan/PPHP/PPSPM/Bendahara/A PIP dalam menghadapi permasalahan hukum dalam lingkup Pengadaan Barang/Jasa Pemerintah.

2. Pasal 115 ayat 4 menyatakan bahwa Khusus untuk tindak pidana dan pelanggaran persaingan usaha, pelayanan hukum sebagaimana dimaksud pada ayat (3) hanya diberikan hingga tahap penyelidikan.

Perbedaan Antara Peraturan Presiden

No. 54 Tahun 2010, dan Peraturan Presiden No. 70 Tahun 2012 dengan Peraturan Presiden No. 4 Tahun 2015 tentang Pelayanan Hukum Terhadap Pengelola Pengadaan Barang/Jasa Pemerintah adalah sebagai berikut :

Topik
Hukum

Perpres 54/2010, : Belum diatur dan Perpres 70/2012

Perpres 4/2015

: Pimpinan K/L/D/I

wajib memberikan

pelayanan hukum

kepadaPA/KPA/

PPK/ULP/Pejabat

Pengadaan/PPHP/

PPSPM/Bendahara/

APIP dalam

menghadapi

permasalahan hukum

dalam lingkup

Pengadaan Barang/

Jasa Pemerintah.

Topik : Ruang Lingkup

Perpres 54/2010, : Belum diatur

dan Perpres 70/2012

Perpres 4/2015 : Pelayanan hukum

hanya diberikan

hingga tahap

penyelidikan untuk

tindak pidana dan

pelanggaran

persaingan usaha

Ketentuan ini bertujuan untuk memberikan perlindungan hukum kepada pengelola pengadaan sehingga dapat melaksanakan tugasnya secara baik dan tenang. Juga untuk memastikan bahwa $\mathrm{K} / \mathrm{L} / \mathrm{D} / \mathrm{I}$ tetap bertanggungjawab dalam proses pengadaan barang/jasa.

\section{METODE PENELITIAN}

\section{Etika Pengelola Pengadaan Barang/Jasa}

Pengadaan barang/jasa harus dilakukan dengan menjunjung tinggi etika pengadaan. Pengamalan terhadap etika pengadaan diharapkan dapat membuat pengadaan barang/jasa berlangsung dengan baik. Etika pengadaan barang/jasa meliputi:

1. Melaksanakan tugas secara tertib, disertai rasa tanggung jawab untuk mencapai sasaran, kelancaran dan ketepatan tercapainya tujuan Pengadaan Barang/Jasa; 
2. Bekerja secara profesional dan mandiri, serta menjaga kerahasiaan Dokumen Pengadaan Barang/Jasa yang menurut sifatnya harus dirahasiakan untuk mencegah terjadinya penyimpangan dalam Pengadaan Barang/Jasa;

3. Tidak saling mempengaruhi baik langsung maupun tidak langsung yang berakibat terjadinya persaingan tidak sehat;

4. Menerima dan bertanggung jawab atas segala keputusan yang ditetapkan sesuai dengan kesepakatan tertulis para pihak;

5. Menghindari dan mencegah terjadinya pertentangan kepentingan para pihak yang terkait, baik secara langsung maupun tidak langsung dalam proses Pengadaan Barang/Jasa;

6. Menghindari dan mencegah terjadinya pemborosan dan kebocoran keuangan negara dalam Pengadaan Barang/Jasa;

7. Menghindari dan mencegah penyalahgunaan wewenang dan/atau kolusi dengan tujuan untuk keuntungan pribadi, golongan atau pihak lain yang secara langsung atau tidak langsung merugikan negara; dan

8. Tidak menerima, tidak menawarkan atau tidak menjanjikan untuk memberi atau menerima hadiah, imbalan, komisi, rabat dan berupa apa saja dari atau kepada siapapun yang diketahui atau patut diduga berkaitan dengan Pengadaan Barang/Jasa

Apabila terjadi pelanggaran, sesuai dengan kewenangannya, pimpinan K/L/D/I dapat memberikan sangsi baik kepada penye dia maupun kepada PPK/ULP/Pejabat Pengadaan. Sanksi yang dapat diberikan kepada penyedia karena pelanggaran tersebut berupa :

a. sanksi administratif;

b. sanksi pencantuman dalam Daftar Hitam;

c. gugatan secara perdata; dan/atau

d. pelaporan secara pidana kepada pihak berwenang.

\section{Pelayanan Hukum Terhadap Pengelola Pengadaan Barang dan Jasa}

Menurut Peraturan Presiden Nomor 4 Tahun 2015, Pelayanan Hukum Terhadap Pengelola Pengadaan Barang dan Jasa yaitu:

1. Pasal 115 ayat 3 menyatakan bahwa Pimpinan K/L/D/I wajib memberikan pelayanan hukum kepada PA/KPA/PPK/ULP/Pejabat

Pengadaan/PPHP/PPSPM/Bendahara/A PIP dalam menghadapi permasalahan hukum dalam lingkup Pengadaan Barang/Jasa Pemerintah.

2. Pasal 115 ayat 4 menyatakan bahwa Khusus untuk tindak pidana dan pelanggaran persaingan usaha, pelayanan hukum sebagaimana dimaksud pada ayat (3) hanya diberikan hingga tahap penyelidikan.

\section{KESIMPULAN}

Pengadaan barang/jasa harus dilakukan dengan menjunjung tinggi etika pengadaan. Pengamalan terhadap etika pengadaan diharapkan dapat membuat pengadaan barang/jasa berlangsung dengan baik. Etika pengadaan barang/jasa meliputi:

1. Melaksanakan tugas secara tertib, disertai rasa tanggung jawab untuk mencapai sasaran, kelancaran dan ketepatan tercapainya tujuan Pengadaan Barang/Jasa;

2. Bekerja secara profesional dan mandiri, serta menjaga kerahasiaan Dokumen Pengadaan Barang/Jasa yang menurut sifatnya harus dirahasiakan untuk mencegah terjadinya penyimpangan dalam Pengadaan Barang/Jasa;

3. Tidak saling mempengaruhi baik langsung maupun tidak langsung yang berakibat terjadinya persaingan tidak sehat;

4. Menerima dan bertanggung jawab atas segala keputusan yang ditetapkan sesuai dengan kesepakatan tertulis para pihak;

5. Menghindari dan mencegah terjadinya pertentangan kepentingan para pihak yang terkait, baik secara langsung maupun tidak langsung dalam proses Pengadaan Barang/Jasa; 
6. Menghindari dan mencegah terjadinya pemborosan dan kebocoran keuangan negara dalam Pengadaan Barang/Jasa;

7. Menghindari dan mencegah penyalahgunaan wewenang dan/atau kolusi dengan tujuan untuk keuntungan pribadi, golongan atau pihak lain yang secara langsung atau tidak langsung merugikan negara; dan

8. Tidak menerima, tidak menawarkan atau tidak menjanjikan untuk memberi atau menerima hadiah, imbalan, komisi, rabat dan berupa apa saja dari atau kepada siapapun yang diketahui atau patut diduga berkaitan dengan Pengadaan Barang/Jasa

Menurut Peraturan Presiden Nomor 4

Tahun 2015, Pelayanan Hukum Terhadap Pengelola Pengadaan Barang dan Jasa yaitu:

1. Pasal 115 ayat 3 menyatakan bahwa Pimpinan K/L/D/I wajib memberikan pelayanan hukum kepada PA/KPA/PPK/ULP/Pejabat

Pengadaan/PPHP/PPSPM/Bendahara/A PIP dalam menghadapi permasalahan hukum dalam lingkup Pengadaan Barang/Jasa Pemerintah.

2. Pasal 115 ayat 4 menyatakan bahwa Khusus untuk tindak pidana dan pelanggaran persaingan usaha, pelayanan hukum sebagaimana dimaksud pada ayat (3) hanya diberikan hingga tahap penyelidikan.

\section{REFERENSI}

Peraturan Presiden Nomor 54 Tahun 2010, Tentang Pengadaan Barang/Jasa Pemerintah

Peraturan Presiden Nomor 70 Tahun 2012,

Tentang Perubahan Kedua Atas

Peraturan Presiden Nomor 54 Tahun 2010 Tentang Pengadaan Barang/Jasa Pemerintah.

Peraturan Presiden Nomor 4 Tahun 2015,

Tentang Perubahan Keempat Atas

Peraturan Presiden 54/2010 tentang Pengadaan Barang/ Jasa Pemerintah
Syah Sirikit, Media Massa Di bawah Kapitalisme, Pustaka Pelajar, Yogyakarta 1999.

Tim lembaga Informasi Nasional, Delik Pers

Dalam Hukum Pidana, Dewan Pers Dan Lembaga Informasi Nasional, Jakarta 2002. 